\title{
Identifying Factors that Influence Inter- national Student Mobility in Chinese Higher Education Institutions
}

\author{
Le Kang, Fulin Li, Yan Li \\ Dalian University of Technology, Dalian, China
}

\begin{abstract}
International student mobility has been becoming varied and complex. Chinese higher education institutions (HEIs) host about 492,185 international students in 2018, sharing 10 percent of globally mobile students. The purpose of the study was to promote understanding of factors that influence international students choose to earn academic degree in Chinese HEIs. The econometric approach was applied to identify factors that influence international student mobility in China. The total inflow of international students, the inflow of students from both developing and developed countries, and international students with undergraduate, master's and doctoral academic programs are taken as predicted variables. The political, economic, academic, socio-cultural factors were chosen as explanatory variables. From the sample data of 60 countries of origin, our data covers more than $89 \%$ of total international students earn academic degrees in Chinese HEIs during the period 2007 to 2016. The results indicated some differences in determinants of undergraduate students, master's students and doctoral students from developing and developed countries choose to study in China. The economic development level between China and the countries of origin and their bilateral trade relations are important economic factors that affect international students, and the impact on undergraduate students is more significant. The Chinese government scholarship policies and mutual recognition of academic degrees have been effectively promoted inward international students. Compared with undergraduate students, the academic ranking of Chinese universities has more significant influences on master's students and doctoral students. The geographical dis-
\end{abstract}

Keywords: International Student Mobility; Study in China; Determinants 
tance and cultural distance between China and the countries of origin are important social and cultural factors. International students from developed countries are more influenced by cultural distance factor.

Sci Insigt Edu Front 2019; 4(1):339-354. Doi: 10.15354/sief.19.ar107

About the Authors: Fulin Li, MA candidate, Graduate School of Education, Dalian University of Technology, Dalian, China, Email: lifulin19940312@mail.dlut.edu.cn;

Yan Li, Assistant Professor, Department of Public Administration, Dalian University of Technology, China, Email: liyandlut@dlut.edu.cn;

Correspondence to: Le Kang, Associate Professor, Graduate School of Education, Director of Institute of Higher Education Policy and Management, Dalian University of Technology, Dalian, China, Email: kangle@dlut.edu.cn.

Funding: This work was supported by the China Association for International Education under Grant (\#2018-2019Y015).

Conflict of Interests: None. 
I NTERNATIONAL student mobility has been becoming complex and varied since traditional emigrant international student source countries like China are start to receive a significant number of international students. The continuation of growth in international student mobility indicated the increasing capacity in inclusive and equitable quality education provision within certain countries.

Recent data indicates that Chinese higher education institutions (HEIs) host about 492,185 international students in 2018, sharing 10 percent of globally mobile students. 63,041 international students were sponsored by Chinese Government Scholarship, shared $12.81 \%$ of the total international students. The percentage of international students pursued higher education degrees in Chinese HEIs grew from $46.34 \%$ in 2017 to $52.44 \%$ in 2018 , international students pursued either master's or doctorate degree increased to $17.3 \%$ in 2018 (MOE, 2018).

Compared to top destination for international students, the percentage of international students enrolled in China's degree programs is smaller than the United Kingdom and the United States. However, the overall robust growth in international student enrollment between 2007 and 2018 has indicated China has the ability to cultivate more talents for the world. The Chinese central government has urged universities to actively engage international exchanges and cooperation get proactive and strategic in attracting and supporting international students. It can be predicted that when China enter the stage of universal higher education after 2020, Chinese prestigious universities with broader strategic vision will speed up the pace of growth in international enrollment, and the overall international student enrollment is likely to increase for most universities. In this context, illuminating influence factors of international student mobility in China is critical to policymakers and higher education administrators.

\section{Research Background}

International student mobility is an important theme of the internationalization of higher education. It is clear that there are different determinants for international student mobility. These are not mutually exclusive, may be different in importance by country and region, and can change in dominance over time.

In the empirical literature attempted to identify the determinants of international student mobility, Beine et al. (2014) estimated the importance of factors from data that cover 180 countries of origin and 13 OECD economies as destination countries over the period of 2004 to 2007. By the multi-origin and multi-destination research framework, they find language, migration network, quality of higher education and university rankings have positive impacts, geographical distance and migration cost have negative impacts on international student flows to destination countries. Abbott and Silles (2016) estimated the importance of factors by using data from 18 destination countries and 38 countries of origin over the period 2005 to 2011. The study also confirmed that international students prefer to study in countries that share the same language, and geographical distance significantly reduced international students from economically disadvantaged countries. 
With the implementation of macro international education policies such as "Study in China", the expansion of the scale of international students in China arouse research interests of scholars. Song and Liu (2014) investigated the determinants of international students in China by employing the gravity model with a sample of international students from 22 countries from 1997-2012. The main findings showed that international students were attracted by China's continuous economic development and promising development potential, bilateral economic linkage with China, mutual recognition of academic credentials and degrees. Wang and Chen (2018) found that economic development level, bilateral economic cooperation, educational opportunities and education quality, mutual recognition of academic credentials and degrees, international students' scholarship opportunities, and geographical distance all have significant impact on graduate students from the Belt and Road countries choose to study in China. Geographical distance and linguistic discrepancies have been considered as obstructive factors in those studies of Chinese scholars.

These empirical literature provides important insights into identify the determinants of international student mobility. However, there are certain limitations in previous empirical studies. On the one hand, previous studies mainly focused on international student mobility in developed countries and prestigious institutions, less attention has been paid to the determinants of international student mobility in developing countries. The increasing competition for international students and academics in developing countries like China cannot be ignored. On the other hand, previous research mainly treated international students as a whole group, failing to reveal the differences in motivation and influencing factors between international students enrolled in undergraduate, master's and doctoral academic programs and short-term exchange students.

\section{Theoretical Framework}

It is quite complex to develop a comprehensive understanding of the determinants of international student mobility. de Wit (2010) identified four broad categories of rationales for internationalization of higher education: political, economic, academic, social and cultural rationales. These four categories have been widely accepted by many scholars around the world. This theoretical framework can be used in Our study to examine the determinants of international student mobility.

In order to measure political rationales, our study focus on Chinese government policies act on the attraction of international students, such as Chinese Government Scholarship policy that support international students to study in HEIs, government policies about international reciprocity in academic degrees and mutual recognition of academic degrees.

As Wei (2013) identified in previous research, in the case of students from developing countries, they, compared with students from developed countries, put more weight on the economic factors, such as per capita GDP gap between countries, higher education expenditure as percentage of GDP, and purchasing power parity. We choose per capita GDP gap between countries and bilateral trade volume as economic factors. 
We assume larger volume of bilateral commodity trade has a positive and significant correlation with international student mobility.

Among those academic factors, Van and Veugelers (2013), Beine (2014) found that the quality of higher education had a positive and significant effect on the flows of international students. University international rankings seem to become more dominant variable to measure academic factors (Brezis \& Soueri, 2011). Thus, our study chooses university international academic rankings as an independent variable.

International students are crossing geographic and cultural borders in the pursuit of an international education. This study chose geographical distance and cultural distance to measure social and cultural factors. This study assumed that a country has strong culture links with China, with closer geographical distance and smaller cultural distance; their students are more inclined to study in Chinese HEIs.

\section{Research Design}

This study uses a multi-origin framework to identify the main factors affecting international students earn academic degree in Chinese HEIs. The study attempted to estimate the importance of those factors using macro-level panel data covering undergraduate students, master's students and doctoral students study in Chinese HEIs during the period 2007 to 2016. We selected 60 countries of origin, the number of international students from these countries covers more than $89 \%$ of international students earn higher education degrees in Chinese HEIs.

In the period 2007 to 2016, due to the widespread impact of the global financial recession, there were severe budget-cuts in higher education sector in developed economies. As the recession moved from the US to Europe and Australia, many public universities faced the challenge of supporting international students. At the same time, with GDP rapid growth, Chinese government invested significantly in higher education sector, and pushed HEIs towards offering affordable and accessible academic programs, thus fueling international student mobility in Chinese HEIs. The Chinese government funding for international students was 0.942 billion CNY in 2007, 1.55 billion CNY in 2012, up to 2.388 billion CNY in 2016. The total amount of international students in China was 195,503 in 2007, up to 442,773 in 2016, 492,185 in 2018. The overall numbers of international students and the ratio of degree students had been steadily climbing over a ten-year period (Table 1).

\section{The Econometric Model}

The econometric approach was applied to identify the determinants of international student mobility in HEIs in China. The political, economic, academic and socio-cultural factors were chosen as explanatory variables.

To investigate the determinants of international student mobility, an econometric model can be described as the following equation: 


\begin{tabular}{|c|c|c|c|}
\hline Year & Intl. Students-Total & Intl. Students-Degree & Ratio \\
\hline 2007 & 195,503 & 68,213 & $34.89 \%$ \\
\hline 2008 & 223,499 & 80,005 & $35.80 \%$ \\
\hline 2009 & 238,184 & 93,450 & $39.23 \%$ \\
\hline 2010 & 265,090 & 107,432 & $40.53 \%$ \\
\hline 2011 & 292,611 & 118,837 & $40.61 \%$ \\
\hline 2012 & 328,330 & 133,509 & $40.66 \%$ \\
\hline 2013 & 356,499 & 147,890 & $41.48 \%$ \\
\hline 2014 & 377,054 & 164,394 & $43.60 \%$ \\
\hline 2015 & 397,635 & 184,799 & $46.47 \%$ \\
\hline 2016 & 442,773 & 209,966 & $47.42 \%$ \\
\hline
\end{tabular}

In (international students $\left.{ }_{\mathrm{cjt}}\right)=\partial_{0}+\beta_{1}$ GDPpc ratio $\mathrm{cj} t+\beta_{2} \ln \left(\right.$ trade $\left._{\mathrm{cjt}}\right)+\beta_{3} \ln \left(\right.$ distance $\left._{\mathrm{cjt}}\right)$

$$
+\beta_{4} \text { rank }_{\mathrm{ct}}+\beta_{5} \text { scholarship }_{\mathrm{cjt}}+\beta_{6} \text { other }_{\mathrm{cjt}}+\varepsilon_{\mathrm{cjt}}
$$

In this equation, the predicted variable is the "number of international students enrolled in Chinese HEIs in the $t$ period". A way to measure international student mobility is to use the numbers of international students enrolled in higher education in the host country. Hence, factors that influence enrollment numbers can be seen to represent factors that influence international student mobility.

The subscript $\mathrm{c}$ and $\mathrm{j}$ respectively represent China and the country of origin. The time is represented by $t$.

International students' ${ }_{c j t}$ represents number of international students from the origin country $\mathrm{j}$ taking admissions in undergraduate, master or doctoral academic programs in Chinese HEIs in the t period.

The ratio of China's GDP per capita to the source country's GDP per capita indicates per capita GDP gap between China and source countries.

cjt represents the bilateral influencing factors of the time period, while ct represents the destination factors of the t-period.

Other cit includes two control variables: Cultural distance and mutual recognition of academic degrees.

$\partial_{0}$ represents a constant term. $\varepsilon$ cjt represents a random perturbation term.

\section{Selection of Variables}

\section{Data Sources}

The data mainly collected from the Statistics of International Students in China compiled by the Department of International Cooperation and Exchange of MOE.

The data of GDP per capita and bilateral trade volume of commodities are collected from the World Bank database and China's National Bureau of Statistics. 


\section{Table 2. List of Variables.}

\begin{tabular}{|c|c|c|}
\hline Variable & Description & Source \\
\hline \multicolumn{3}{|l|}{ Predicted Variable } \\
\hline $\begin{array}{l}\text { International stu- } \\
\text { dents }\end{array}$ & $\begin{array}{l}\text { Number of degree students who taking admissions in } \\
\text { undergraduate, master or doctoral programs in Chinese } \\
\text { HEls. }\end{array}$ & $\begin{array}{l}\text { Statistics of Interna- } \\
\text { tional Students in } \\
\text { China } \\
\text { Ministry of Educa- } \\
\text { tion, China }\end{array}$ \\
\hline \multicolumn{3}{|c|}{ Explanatory Variables } \\
\hline $\begin{array}{l}\text { Ratio of GDP per } \\
\text { capita }\end{array}$ & $\begin{array}{l}\text { The ratio of per capita Gross Domestic Product (GDP) in } \\
\text { China to per capita GDP in the international student } \\
\text { source countries. }\end{array}$ & $\begin{array}{l}\text { World Bank Devel- } \\
\text { opment Indicators } \\
\text { China's National } \\
\text { Bureau of Statistics }\end{array}$ \\
\hline $\begin{array}{l}\text { Bilateral trade vol- } \\
\text { ume }\end{array}$ & $\begin{array}{l}\text { Total import and export commodities between China and } \\
\text { source countries. }\end{array}$ & $\begin{array}{l}\text { World Bank Devel- } \\
\text { opment Indicators } \\
\text { National Bureau of } \\
\text { Statistics, China }\end{array}$ \\
\hline $\begin{array}{l}\text { Geographical dis- } \\
\text { tance }\end{array}$ & The distance between the capital cities. & CEPII \\
\hline Cultural distance & $\begin{array}{l}\text { The differences of cultural values amongst countries. } \\
\text { If international student source country belongs to the } \\
\text { Confucian cultural circle, take } 1 \text {, otherwise take } 0 \text {. }\end{array}$ & $\begin{array}{l}\text { Relevant historical } \\
\text { documents }\end{array}$ \\
\hline University ranking & $\begin{array}{l}\text { The proportion of Chinese universities in the top } 500 \\
\text { universities of the Academic Ranking of World Universi- } \\
\text { ties. }\end{array}$ & $\begin{array}{l}\text { Shanghai Ranking } \\
\text { official publisher }\end{array}$ \\
\hline $\begin{array}{l}\text { Chinese govern- } \\
\text { ment scholarship }\end{array}$ & $\begin{array}{l}\text { Government scholarship policies that support interna- } \\
\text { tional students to study in China. } \\
\text { The proportion of Chinese government scholarship } \\
\text { awarded to international students of source countries to } \\
\text { total international students with Chinese government } \\
\text { scholarship. }\end{array}$ & $\begin{array}{l}\text { Statistics of Interna- } \\
\text { tional Students in } \\
\text { China } \\
\text { Ministry of Educa- } \\
\text { tion, China }\end{array}$ \\
\hline $\begin{array}{l}\text { Mutual recognition } \\
\text { of academic de- } \\
\text { grees }\end{array}$ & $\begin{array}{l}\text { International reciprocity in academic degrees, mutual } \\
\text { recognition of academic degrees between China and } \\
\text { source countries. }\end{array}$ & $\begin{array}{l}\text { Ministry of Educa- } \\
\text { tion, China }\end{array}$ \\
\hline
\end{tabular}

Geographic distance data are collected from CEPII database.

The data of university ranking are collected from Shanghai Ranking's Academic Ranking of World Universities.

Other data are collected from the website of MOE and related literature. All data in our study do not include Hong Kong, Macao and Taiwan.

Table 3 shows the descriptive statistics of all the variables included in the analysis.

\section{Measuring Determinants}


Table 3. Summary Statistics.

\begin{tabular}{|c|c|c|c|c|c|}
\hline Variable & Obs & Mean & SD & Min & Max \\
\hline Intl students-degree & 600 & $1,942.502$ & $3,796.906$ & 10 & 26,921 \\
\hline $\begin{array}{l}\text { Intl students of } \\
\text { Developing countries }\end{array}$ & 440 & $1,818.811$ & $2,684.452$ & 23 & 16,781 \\
\hline $\begin{array}{l}\text { Intl students of } \\
\text { Developed countries }\end{array}$ & 160 & $2,282.65$ & $5,852.849$ & 10 & 26,921 \\
\hline Undergraduate students & 600 & $1,450.317$ & $3,162.436$ & 6 & 23,176 \\
\hline Master's students & 600 & 363.910 & 557.756 & 3 & 3,019 \\
\hline PhD students & 600 & 128.275 & 314.490 & 0 & 4,582 \\
\hline Ratio of GDP per capita & 600 & $14,240.740$ & $18,482.973$ & 272.391 & $61,174.545$ \\
\hline Bilateral trade volume ${ }_{\mathrm{cjt}}$ & 600 & $40,069.497$ & $75,304.59$ & 58.43 & $557,022.7$ \\
\hline University ranking ct & 600 & 0.076 & 0.017 & 0.050 & 0.108 \\
\hline China scholarships $\mathrm{cjt}$ & 600 & $23,713.8$ & $11,206.733$ & 6615 & 43,186 \\
\hline Mutual recognition ${ }_{\mathrm{cjt}}$ & 600 & 0.517 & 0.500 & 0 & 1 \\
\hline Geographical distance $_{\mathrm{cj}}$ & 600 & $6,709.713$ & $3,340.807$ & 809.85 & $16,928.99$ \\
\hline Cultural distance $_{\mathrm{cj}}$ & 600 & 0.200 & 0.400 & 0 & 1 \\
\hline
\end{tabular}

\section{Regression Analysis on Determinants of International Student Mobility in China}

This study used Stata 14.0 to analyze and estimate samples using fixed effects model and random effects model, respectively. Hausman test was carried out on the estimation results, and the test value is 35.96 (DOF 5), $\mathrm{P}$ value is 0.0000 , strongly rejecting the original hypothesis (random effect), indicating that the fixed effects model should be selected (Table 4). In addition, by examining the problems of inter-group heteroscedasticity, sequence correlation and intra-group autocorrelation that may exist in the model, the test results showed that the original hypothesis was strongly rejected. Therefore, this study used clustering robust standard deviation to eliminate the effects of heteroscedasticity and sequence correlation.

Under the Fixed-effects model, the variables of "the ratio of GDP per capita of China to the countries of origin" and "bilateral trade volume in total" were significantly positive at the $1 \%$ confidence level. The result implies that with the economic development of China, the more trade cooperation with the countries of origin, the more favorable it will be for China to attract its international students.

"Geographical distance" is significantly negative at the $1 \%$ confidence level, indicating that distance was still one of the obstacles for international students studying in China.

"International ranking of Chinese universities" and "Chinese government scholarship" were significantly positive at the confidence level of $1 \%$ and $5 \%$, indicating that the quality of higher education in China is the main factor attracting 


\section{Table 4. Analysis of the Regression Results of the Determinants of International Student Mobility.}

\begin{tabular}{|c|c|c|c|}
\hline Variable & M1-Intl. Students Fixed-Effects & Random-Effects & VIF \\
\hline \multirow[t]{2}{*}{ Ratio of GDP pc } & $0.163^{\star \star \star}$ & $0.138^{* \star *}$ & 1.75 \\
\hline & (3.96) & $(4.75)$ & \\
\hline \multirow[t]{2}{*}{ Intrade } & $0.259^{* * *}$ & $0.293^{\star * \star}$ & 1.73 \\
\hline & $(5.92)$ & $(7.79)$ & \\
\hline \multirow[t]{2}{*}{ Indistance } & $-0.032^{\star * *}$ & $-0.034^{\star \star *}$ & 1.54 \\
\hline & $(-7.51)$ & $(-8.32)$ & \\
\hline \multirow[t]{2}{*}{ Ranking } & $19.869^{* * *}$ & $18.701^{* * *}$ & 1.34 \\
\hline & $(10.96)$ & $(10.82)$ & \\
\hline \multirow[t]{2}{*}{ Scholarships } & $6.591^{* *}$ & $11.718^{\star \star \star}$ & 1.23 \\
\hline & $(2.55)$ & $(4.70)$ & \\
\hline \multirow[t]{2}{*}{ Constant } & $3.265^{\star \star \star}$ & $3.150^{\star * \star}$ & \\
\hline & $(10.07)$ & $(9.87)$ & \\
\hline Hausman & $35.96(0.0000)$ & & \\
\hline Obs & 600 & 600 & 600 \\
\hline $\mathrm{R}^{2}$ & 0.760 & 0.746 & \\
\hline
\end{tabular}

international students to study in China, and Chinese government scholarship is an important policy lever to effectively increase the number of international students from the countries of origin.

\section{Classification Regression Results Based on Different Coun- tries and Different Levels of Chinese HEIs}

International students studying in Chinese HEIs came from 196 countries and regions. Top ten countries of origin with the largest number of international students were Korea (with 50,600 students), Thailand (with 28,608 students), Pakistan (with 28,023 students), India (with 23,198 students), the United States (with 20,996 students), Russia (with19,239 students), Indonesia (with 15,050 students), Laos (with 14,645 students), Japan (with 14,230 students) and Kazakhstan (with 11,784 students) (MOE, 2018).

We selected top 60 source countries in global range, as listed in Table 5. The selected countries were divided into 44 developing countries and 16 developed countries according to the classification criteria of the World Bank, which were brought into model 2-3 for analysis. The international students was divided into undergraduate students, master's students and $\mathrm{PhD}$ students groups, and the regression analysis was carried out in model 4, 5 and 6.

The results of the Hausman test showed that the five models strongly reject thenull hypothesis (random effect), indicating that the fixed effect model should be 


\section{Table 5. Sixty Major Countries of Origin.}

Forty Four Thailand, Pakistan, India, Russia, Indonesia, Kazakhstan, Vietnam, Laos, Developing Mongolia, Malaysia, Myanmar, Nepal, Bangladesh, Kyrgyzstan, Yemen, UzCountries bekistan, Philippines, Tajikistan, Sri Lanka, Cambodia, Turkmenistan, Saudi Arabia, Turkey, Korea, Iraq, Iran, Jordan, Nigeria, Tanzania, Zambia, Zimbabwe, Cameroon, Kenya, Ethiopia, Sudan, South Africa, Rwanda, Mauritius, Egypt, Brazil, Mexico, Ukraine, Belarus

Sixteen Korea, US, Japan, Singapore, Canada, France, Germany, UK, Italy, Australia,
Developed Spain, Netherlands, Poland, Sweden, Belgium, Denmark Countries

selected. The regression results of model 2 showed that for the international students of developing countries, the "bilateral trade volume in total" and "Chinese university rankings" were significantly positive at the $1 \%$ confidence level.

The regression results of model 3 showed (Table 6) that for the international students of developed countries, "ratio of GDP per capita" was significantly positive at the $1 \%$ confidence level, "Chinese university rankings" were significantly positive at the $10 \%$ confidence level, and "geographic distance" factor was negative at $10 \%$ confidence level.

Comparing the results of model 2 and 3, international students of developing countries were more influenced by "bilateral trade volume", "university international ranking", "geographic distance" and "China government scholarship".

The empirical analysis results of model 4, 5 and 6 showed that the ratio of GDP per capita between China and source countries, and the international academic ranking of Chinese universities were significantly positive at $1 \%$ confidence level for undergraduate, master and doctoral students. "Bilateral trade volume" had a significant positive correlation with $1 \%$ confidence level of undergraduate and master students, and had a greater impact on undergraduate students and master students, but had no significant impact on doctoral students. More $\mathrm{PhD}$ candidates with professional academic training were inclined to find a job in universities or institutes, so they were less influenced by international trade.

\section{Regression Analysis under Random Effects Model}

The study selected "cultural distance" and "mutual recognition of academic degrees" as control variables. The control variables were fictitious variables and have zero values; the random effect model was used to capture variables that were unobservable and invariant at the national level.

From the regression results in Table 7, "cultural distance" was significantly positive at $1 \%$ confidence level, and "mutual recognition of academic degrees" was 


\section{Table 6. Classified Regression Results.}

\begin{tabular}{|c|c|c|c|c|c|}
\hline Variable & M2 & M3 & M4 & M5 & M6 \\
\hline \multirow{2}{*}{ Ratio of GDP pc } & $0.110^{\star *}$ & $7.768^{\star \star \star}$ & $0.202^{\star \star \star}$ & $0.157^{\star * *}$ & $0.220^{\star * *}$ \\
\hline & $(2.47)$ & $(2.91)$ & $(4.41)$ & (3.33) & $(4.50)$ \\
\hline \multirow{2}{*}{ Intrade } & $0.216^{* * *}$ & 0.355 & $0.298^{* * *}$ & $0.232^{* * *}$ & 0.051 \\
\hline & $(4.72)$ & $(1.59)$ & $(6.15)$ & $(4.64)$ & $(0.98)$ \\
\hline \multirow{2}{*}{ Indistance } & $-0.035^{\star * *}$ & $-0.018^{*}$ & $-0.040^{* * *}$ & -0.008 & $-0.017^{* * *}$ \\
\hline & $(-7.23)$ & $(-1.94)$ & $(-8.53)$ & $(-1.54)$ & $(-3.38)$ \\
\hline \multirow{2}{*}{ Ranking } & $22.528^{* * *}$ & $8.208^{*}$ & $14.683^{\star * *}$ & $31.640^{* * *}$ & $28.825^{\star * *}$ \\
\hline & $(10.19)$ & $(1.75)$ & $(7.29)$ & $(15.22)$ & $(13.37)$ \\
\hline \multirow{2}{*}{ Scholarships } & $5.255^{*}$ & 8.061 & 2.083 & $21.531^{* * *}$ & $19.390^{* * *}$ \\
\hline & $(1.81)$ & $(1.36)$ & $(0.72)$ & $(7.26)$ & $(6.34)$ \\
\hline \multirow{2}{*}{ Constant } & $3.687^{* * *}$ & 1.727 & $2.944^{\star * *}$ & 0.469 & $0.669^{*}$ \\
\hline & $(11.18)$ & $(0.90)$ & $(8.16)$ & $(1.26)$ & $(1.72)$ \\
\hline \multirow{2}{*}{ Hausman } & 24.52 & 14.09 & 29.93 & 18.96 & 28.86 \\
\hline & $(0.0002)$ & $(0.0150)$ & $(0.0000)$ & $(0.0020)$ & $(0.0000)$ \\
\hline $\mathrm{Fe}$ & Yes & Yes & Yes & Yes & Yes \\
\hline Obs. & 440 & 160 & 600 & 600 & 600 \\
\hline$R^{2}$ & 0.788 & 0.681 & 0.710 & 0.752 & 0.715 \\
\hline
\end{tabular}

significantly positive at $5 \%$ confidence level.

The regression results of model 2-3 showed that the "cultural distance" factor was significantly positive in both developing and developed countries group, with the confidence level of 5\% and 1\% respectively. Regression results of model 4-6 showed that "cultural distance" was significantly positive for all international students at $1 \%$ confidence level. This means that although there are great cultural differences between the countries of origin and China, the scale of the students studying in China can also grow.

A positive statistically significant relation of mutual recognition of academic degrees, as found, the confidence level of "mutual recognition of academic degrees" for undergraduate students and master's students was significantly positive at $5 \%$ and $10 \%$, respectively. "Mutual recognition of academic degrees" had a positive effect on international students, but it was not significant for PhD students.

\section{Conclusion and Policy Implications}




\begin{tabular}{|c|c|c|c|c|c|c|}
\hline Variable & $\begin{array}{l}\text { M1 } \\
\text { Intl. Stu- } \\
\text { dents }\end{array}$ & $\begin{array}{l}\text { M2 } \\
\text { Intl. Students } \\
\text { of Develop- } \\
\text { ing Countries }\end{array}$ & $\begin{array}{l}\text { M3 } \\
\text { Intl. Stu- } \\
\text { dents of } \\
\text { Developed } \\
\text { Countries }\end{array}$ & $\begin{array}{l}\text { M4 } \\
\text { BA Stu- } \\
\text { dents }\end{array}$ & $\begin{array}{l}\text { M5 } \\
\text { MA Stu- } \\
\text { dents }\end{array}$ & $\begin{array}{l}\text { M6 } \\
\text { PhD Stu- } \\
\text { dents }\end{array}$ \\
\hline \multirow[t]{2}{*}{ GDPpc ratio } & $0.160^{\star \star \star}$ & $0.104^{\star \star \star}$ & $4.748^{\star \star}$ & $0.193^{\star \star \star}$ & $0.118^{\star \star \star}$ & $0.146^{\star \star \star}$ \\
\hline & $(5.25)$ & (3.26) & (2.39) & $(5.36)$ & $(4.09)$ & $(4.20)$ \\
\hline \multirow[t]{2}{*}{ Intrade } & $0.306^{\star \star \star}$ & $0.273^{\star \star \star}$ & $0.746^{\star \star \star}$ & $0.346^{\star \star \star}$ & $0.271^{\star \star \star}$ & $0.176^{\star \star \star}$ \\
\hline & $(7.87)$ & (6.38) & $(4.76)$ & (7.63) & $(6.91)$ & (3.90) \\
\hline \multirow[t]{2}{*}{ Cultural_dist. } & $1.058^{\star \star \star}$ & $0.686^{\star \star}$ & $1.506^{\star \star \star}$ & $1.366^{\star \star \star}$ & $0.631^{\star \star \star}$ & $0.925^{\star \star \star}$ \\
\hline & (3.98) & (2.39) & (2.68) & (3.88) & $(2.67)$ & $(2.86)$ \\
\hline \multirow[t]{2}{*}{ Ranking } & $28.294^{\star \star \star}$ & $31.181^{\text {***}}$ & $14.704^{\star \star \star *}$ & $25.642^{* \star \star}$ & $33.590^{* \star *}$ & $32.626^{\star \star \star}$ \\
\hline & (20.32) & (17.69) & (3.84) & $(16.16)$ & (22.99) & $(20.45)$ \\
\hline \multirow[t]{2}{*}{ Scholarship } & $10.005^{\star * *}$ & $8.111^{\star \star *}$ & $11.336^{*}$ & 4.473 & $24.467^{* * *}$ & $21.702^{\star \star \star}$ \\
\hline & $(3.81)$ & $(2.78)$ & $(1.92)$ & $(1.50)$ & $(8.87)$ & $(7.25)$ \\
\hline \multirow[t]{2}{*}{ Recognition } & $0.507^{\star *}$ & $0.553^{\star \star}$ & 0.114 & $0.603^{\star \star}$ & $0.325^{*}$ & -0.231 \\
\hline & $(2.41)$ & $(2.40)$ & $(0.27)$ & $(2.16)$ & $(1.75)$ & $(-0.90)$ \\
\hline \multirow[t]{2}{*}{ Constant } & $1.234^{\star * *}$ & $1.613^{\star * \star}$ & $-2.421^{\star \star}$ & 0.477 & -0.321 & $-0.727^{* *}$ \\
\hline & $(4.34)$ & $(5.48)$ & $(-2.10)$ & (1.39) & $(-1.14)$ & $(-2.17)$ \\
\hline Re. & Yes & Yes & Yes & Yes & Yes & Yes \\
\hline Obs. & 600 & 440 & 160 & 600 & 600 & 600 \\
\hline $\mathbf{R}^{2}$ & 0.733 & 0.758 & 0.665 & 0.669 & 0.750 & 0.705 \\
\hline
\end{tabular}

Our study has analyzed the determinants of international student mobility in Chinese HEIs. And found that,

First, Chinese government scholarship policy and mutual recognition of academic degrees between China and origin countries are important political factors that influenced international student mobility in Chinese HEIs. Compared with international students of developed countries, those from the developing countries are more influenced by China government scholarship policy and mutual recognition of academic degrees. Undergraduates and master's students are more concerned about the recognition of academic degrees they earned from Chinese HEIs, whereas doctoral students are not influenced by mutual recognition of academic degrees.

Second, the results indicated that the economic development level and bilateral trade relations are important economic factors that affect international students. Compared with both Master's and Doctoral students, undergraduate students are more likely to be influenced by economic development level and bilateral trade relations. Bilateral trade relations may bring more commercial cooperation and job opportunities for undergraduates. In comparison with international students from the developed countries, those from the developing countries are more influenced by "bilateral trade volume". 
International students of developed countries are more influenced by per capita GDP ratio between China and countries of origin.

Third, the international ranking of the university is an important academic factor affecting international student mobility. Compared with undergraduate students, the international academic ranking of universities has more significant influences on master's and doctoral students. International students from developing countries are more likely to be influenced by university international ranking. In addition, it is easier for international students from developing countries (in particular, countries covered by the Belt and Road Initiative) enrolled in Chinese world-class universities with Chinese government scholarship. Some international programs were developed on some disciplines ranks the top $1 \%$ and $1 \%$ of ESI in the world, while tuition fees and living costs of world-class universities in China are much lower than the US, UK and Australia.

Additionally, another important factor is the geographical and cultural distance between China and countries of origin. Compared with undergraduate students, master's and doctoral students are less likely to be influenced by geographical distance. Compared with students from developed countries, students from developing countries are more likely to be influenced by geographical distance. Cultural distance is significantly positive for all students who are studying from undergraduates, Master's and Doctoral degrees. International students from developed countries are more likely to be influenced by cultural distance factor. The result explained why China has been becoming the most popular destination for Asian students, and Chinese language and literature has been becoming the most popular degree programs among international students from developed countries.

It is worth mentioning certain limitations of our study which can provide further refinement and elaboration on the same theme. First, if researchers have resources to conduct more longitudinal data, it would be better to expand countries of origin, sample data and time span. The second limitation of this study is the variables. "National security" and "foreign policy" should be considered when measuring political factors. Additionally, scholars may consider adding some new social-cultural factors such as internet, environmental quality, cultural characteristics of post-2000s college students in the future empirical studies.

The current trends of international student mobility showed that the interest and demand for gaining global educational experiences remains strong (Choudaha, 2017). However, increasing competitions and expectations on international education require proactive and concerted efforts to maintain a stable inflow of international students. Our findings focus on China, but could be applied to other countries which would like to be an attractive destination or maintain the global competitiveness of international education.

The implication from the findings of this study provides some needed information and evidence to policy makers, higher education administrators and education practitioners. Concerning the determinants of international student mobility, we suggest that, 
Improving the government scholarship policies is important for attracting more promising international students. The scholarship is a big investment on international education in the long run will have an essential impact on international student mobility. The scale of scholarships for international students reflects a kind of soft power of higher education systems. The government scholarships as global public goods, brings more opportunities for international students who have the potential to receive highquality higher education worldwide. As described earlier, Chinese Government Scholarship has proven to be effective in expanding the scale of master's and $\mathrm{PhD}$ students, and enhanced the quality of international students. In 2018, there were 63,000 Chinese Government Scholarship students studying in China, accounting for $12.8 \%$ of the total number of international students. In 2018, 70\% Chinese Government Scholarship sponsored students are master's and $\mathrm{PhD}$ students. However, policy makers still need to pay attention on institutional scholarship policies.

With the expansion of bilateral economic and trade cooperation between China and countries of origin, international students with higher education experience in China has become a competitive group in the labor market. Many international students would like to take advantage of their education experiences and seek to capitalize on the job opportunities presented by China's sustainable economic development and global engagement. We suggest that the local government and universities adjust employment policies and rules for foreign students, support international students find internship program, develop employment opportunities or start businesses in China. Inward international students do have an economic impact on HEIs and enterprises. However, for Chinese higher education providers, main purpose of attracting international students is not pursuing short-time economic profits, they give more weight to gain a better international academic reputation on teaching and research.

The excellence of international ranking means universities are more competitive in attracting international students. The scale of international students is also conducive to universities gaining new competitiveness in some international academic rankings. Beneficial effect of increased international student mobility will only occur if student mobility is guided by education quality considerations in international contexts suggesting that institutions and departments play a role in both producing high-quality education programs and academic support services assurance, so as to encourage international undergraduates to pursuing higher degrees in China.

China has profound cultural tradition and has formed a distinctive and farreaching cultural system through the accumulation of knowledge in thousands of years of civilization. In fact, the cultural differences between the countries of origin and China have not hindered international students, and to some extent, the cultural diversity is in turn important in attracting students from different countries. We suggest Chinese higher education providers give international students more opportunities to in touch with Chinese native students, to participate in more social activities and cultural experience to enhance their understanding of Chinese history and culture. The cultural experience can also be reached by Chinese traditional culture curriculum, intercultural classroom setting, and the teaching and learning process. 
Geographical distance acts as a mobility cost. International students had begun to choose to study at prestigious institutions closer to their home. We suggest the government invest and encourage more Chinese HEIs establish high quality Sino-foreign joint institutions, oversea campuses and deliver transnational education programs in other countries covered by the Belt and Road Initiative. In additional, Chinese HEIs can establish more international student hubs in countries which has strong cultural links with China, it will be easier for these institutions to attract talented and promising international students.

\section{Acknowledgement}

This paper has benefitted from comments and suggestion of participants of CERA-UK Annual Conference 2019 held in UCL Institute of Education.

\section{References}

Abbott A., Silles M. (2016) Determinants of international student migration. World Econ, 621-635.

Altbach P.G., Engberg D. (2014) Global student mobility: The changing landscape. Int Higher Edu, 77:11-13.

Beine M., Noël R., Ragot L. (2014) Determinants of the international mobility of students. Econ Edu Rev, 41: 40-54.

Bouwel L.V., Veugelers R. (2013) The determinants of student mobility in Europe: The quality dimension. Eur J Higher Edu, 3(2):172-190.

Choudaha R. (2017) Three waves of international student mobility (1999-2020). Stud Higher Edu, 42(5):825-832.

De W.H. (2010) Internationalisation of higher education in Europe and its assessment, trends and issues. Accreditation Organisation of the Netherlands and Flanders Publishing, 7-8.

Gonzalez C.R., Mesanza R.B., Mariel, P. (2011) The determinants of international students mobility flows: an empirical study on the Erasmus Programmer. Higher Edu, 62(4): 413-430.

Hao W. (2013) An empirical study on the determinants of international student mobility: a global perspective. Higher Edu, 66:105-122.

http://www.moe.gov.cn/jyb_xwfb/gzdt_gzdt/s 5987/201904/t20190412_377692.html

Levatino A. (2017) Transnational higher education and international student mobility: determinants and linkage: A panel data analysis of enrolment in Australian higher education. Higher Edu, 73: 637-653.

Ministry of Education (2018) Statistics of International Students in China 2018.

Perkins R., Neumayer E. (2014) Geographies of educational mobilities: Exploring the uneven flows of international students. Geograph J, 180(3):246--259.

Song H., Liu L. (2014) Why do foreign students choose to study in China: An empirical study based on the gravity model. J Higher Edu, 35(11):31-38. 
Kang et al. Factors Influence International Student Mobility in China.

Wang C., Chen C. (2018) Factors affecting the postgraduates from the Belt and Road countries to study in China: based on the macro data analysis. J Higher Edu Manag, 12(3):34-42.
Zheng P. (2014) Antecedents to international student inflows to UK higher education: A comparative analysis. J Busin Res, 67(2):136-143.

Received: 03 September 2019

Revised: 27 September 2019

Accepted: 11 October 2019 